\title{
Menyikapi Ulul Albab dalam Alquran
}

\author{
Armyn Hasibuan \\ Institut Agama Islam Negeri Padangsidimpuan \\ Email: armynhasibuan01@gmail.com
}

\begin{abstract}
Abstrak
This paper reveals the meaning of ulul albab by looking at the previous verse and then using the thematic interpretation method. The results obtained from people who are able to read, study, and take sociological and theological value, from the cosmos or universe phenomena that made him have collected the divine by integrating remembrance and thought as well as useful works of art. People who already have the title of ulul al chapters will always be the foremost being drafter, insfirator, motivator and figures who initiate matters which are the benefit of the people in various fields, such as social, social, education, health, politics, law and others.

Keywords: Thematic; Ulul Al-Bab; Alqur'an.

Abstrack

Tulisan ini mengungkap makna ulul albab dengan melihat ayat sebelumnya dan kemudian menggunakan metode tafsir tematik. Hasil yang diperoleh dari orang yang mampu membaca, mengkaji, dan mengambil nilai sosiologis dan teologis, dari fenomena kosmos atau alam raya yang membuat dia telah mengumpulkan ilahiyah dengan mengintegrasikan zikir dan fikir serta karya seni yang bermanfaat. Orang yang telah memiliki predikat ulul al bab akan selalu terdepan menjadi konseptor, insfirator, motivator dan tokoh yang menggagas hal hal yang menjadi kemaslahatan umat di berbagai bidang, seperti sosial, sosial, pendidikan, kesehatan, politik, hukum dan lainlainnya.
\end{abstract}

Kata Kunci: Tematik; Ulul Al-Bab; Alquran. 
Armyn Hasibuan

\section{Pendahuluan}

Apabila kitab zabur diturunkan dengan bahasa Kibty, Taurat dengan bahasa Ibrani, Injil dengan bahasa Suryani, maka Alquran diturunkan dengan bahasa Arabi yang memiliki sastra dan struktur kalimat yang amat slektif dan rapi. Diimankan kepada umat islam bahwa isinya mencakup seluruh isi kandungan kitab yang empat di atas sehingga mengamalkan isi kandungan alquran berarti telah mengamalkan isi kandungan keempat empatnya.

Prof. Dr. Muhammad Saltut sebagai mana dikutip oleh Sahilun A.Naser bahwa Alquran adalah kalam Allah SWT yang diturunkan kepada Muhammad SAW. dengan perantaraan jibril, menjadi mukjizat walau satu ayatpun dan dikera beribadah membacanya. ${ }^{1}$ Di dalam defenisi lain dinyatakan:

القرآن الكريم : هو كلام الله منه بدا بلا كيفية قولا ، وأنزله على رسوله وحيا ، وصدقه المؤمنون على ذلك حقا ، وأيقنوا أنه كلام الله حقيقة ، سمعه جبريل عليه السلام من الله عز وجل ، ونزل به على خاتم رسله محمد صلى الله عليه وسلم بلفظه ومعناه المنقول بالتواتر المفيد للقطع واليقين المكتوب في المصاحف المحفوظ من التغيير والتبديل2

Dari defenisi Alquran pertama di atas, menggambarkan ada tiga kata kunci yaitu : Alquran adalah kalam Allah Swt., sebagai mukjizat dan dikira beribadah membacanya. Pada defenisi kedua dituliskan bahwa Alquran sebagai kalam Allah, pada hakikatnya bukan verbal (بلا كيفية قولا)

1Sahilun A. Nasir, Pendidikan Agama Islam Di Perguruan Tinggi (Surabaya: AlIkhlas, 1998), hlm. 34.

2Fathu Qadir Syaukany, Al Maktabah Syamilah ,Http://ld.m.Wikipedia.Org Diakses Minggu 18 November 2018 Pukul 20.05. 
Allah SWT menurunkannya terhadap hambanNya Muhammad SAW. berupa wahyu, dibenarkan oleh orang-orang yang beriman, mereka yakin bahwa itu kalam Allah Swt. yang diperdengarkan oleh Jibril dan diturunkan kepada nabiNya yang terakhir dengan lafaz, makna yang dinukil secara mutawatir dengan asaz manfaat untuk dapat dipertanggung jawabkan tanpa perubahan dan penggantian.

Pada defenisi kedua ini kata kunci adalah kalam Allah "tidak dengan cara verbal", pada hakikatNya kalam itu tidak terdiri dari huruf, kalimat apalagi suara. Statemen kalimat di atas samalah artinya bila dikatakan Allah berkata kata dengan nabi Musa tidak dengan huruf, tidak dengan suara dan tidak dengan kalimat. Tentu kalimat itu membutuhkan penalaran sebagai lapangan kerja para ulul albab. Lalu, manakala dikatakan hal tersebut tidaklah benar, karena buktinya Alquran ternyata tersusun dari huruf hijaiah mulai dari huruf alif sampai huruf ya, jawabannya itupun benar ! Bagaimana mengkorelasikan keduanya?

Jawabannya, Allah berkeinginan manusia mengetahui apa yang di iradahkanNya, apa yang di dalam iradahNya itu di wujud implementasikanNyalah dengan suatu bahasa yang dapat di pahami, dituturkan dan diartikan oleh manusia itu sendiri, dipilihNyalah bahasa wahyu itu berupa bahasa Arab. agar dapat ditangkap, dipahami dan diimplementasikan oleh manusia sebagai pedoman hidupnya. Akhirnya tampaklah kalamNya yang pada hakikatnya tak pakai huruf, suara dan kalimat itu akhirnya menjadi suatu firman yang baku dan utuh dengan bahasa Arab. 
Allah SWT berfirman dalam surat Yusuf ayat 2 sebagai berikut:

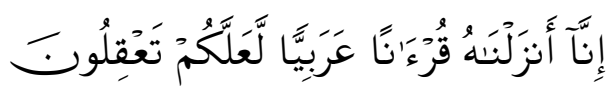

Artinya : Sesungguhnya Kami menurunkannya berupa Alquran dengan berbahasa Arab, agar kamu memahaminya. ${ }^{3}$

Alquran dengan bahasa arabnya memiliki susunan kata yang slektif gremmar yang tinggi terlihat dari wazan fiil ( Pola bentuk kata kerja) dan pelaku ( fail) dari suatu kata kerja (fiil) dapat di ketahui berapa orang, hanya melihat kata kerjanya saja. Pada bentuk verb / fiihya ada tanda pelaku yang mufrad, mutsanna dan yang jamak serta jamak itu serdiri mempunyai tanda pula untuk tunjukan ragam jenis seperti jamak muzakkar, jamak muannas dan jamak taksirlainnya.

Demikian juga istilah istilah dalam Alquran banyak yang memerlukan penafsiran dan pentakwilan yang lahir dari adanya ayat muhkamat apalagi mutasyabihat yakni ayat ayat yang menghajatkan keterangan lebih panjang dan kupasan lebih dalam, tak ada yang dapat menjelaskannya kecuali Allah SWT. dan orang yang banyak ilmu pengetahuannya, cerdas pikirannya, kukuh keimanannya kepada Allah SWT. dan mahir dalam ilmu Alquran. 4

Apatah lagi Alquran merangkai kata atau istilah $u / u l$ albab itu dengan berbagai ayat, secara munasabat kata atau istilah ulul al-bab dihubungkan dengan berbagai substansi hukum dan kejadian sejarah sehingga memerlukan penelusursn yang serius, terjaga dan kondisional. Oleh karena itu tulisan ini akan menyajikan kajian tentang Menyikapi U/ul Albab

3Depag R.I., Al Quran Dan Tarjamahnya ( Jakarta : Lijnah Tahsis Quran,1990), HIm.348.

${ }^{4}$ Akmal N Asery B, Percakapan Cendikiawan Tentang Pembaharuan Pemikiran Islam Di Indonesia ( Bandung: Mizan,1996),HIm. 14. 
dalam Alquran dengan pendekatan tematik ayat, tarekh atau sejarah hidup Rasul dan Sahabat (al-Ma'tsur).

\section{Metode Penelitian}

Dalam rangka menyikapi ulul albab, penulis menelusuri dengan lebih dahulu mencari surah-surah Alquran yang ada di dalamnya-ayat kata/istilah ulul al-bab dengan cara mengambil al-Mu'jam al-Mufarras Bi alFazil Qur'an dan menemukan kata / istilah tersebut 16 kali di sepuluh surah. Adapun ayat-ayat yang di dalamnya ada kata Ulul Al-Bab terdapat pada: 1. Q.S. Al-Baqarah : ayat 179, 197, 269. 2. Q.S. Ali Imran: ayat 7 dan 190. 3. Q.S. Al-Maidah: ayat 100. 4. Q.S. Yusuf: ayat 111. 5. Q.S. ArRa'd: ayat 19. 6. Q.S. Ibrahim: ayat 52. 7. Q.S. Shad: ayat 29 dan 43. 8. Q.S. Az-Zumar: ayat 9, 18 dan 21. 9. Q.S. Ghafir: ayat 54. 10. Q.S. AtThalaq: ayat $10^{5}$

Memperhatikan surah yang ada di dalamnya term ulul albab di atas, dapat dikatakan berimbang antara Makkiyah 8 ayat dan Madaniah juga 8 ayat. Perlu diingat dalam satu surah tidak tertutup kemungkinan ada bercampur antara makkiyah dan madniyah artinya di dalamnya ada satu atau dua ayat yang lain dari keseluruhannya. Misalkan dalam suatu surat makkiyah terdapat di dalamnya satu atau dua ayat madniyah. Adanya keseimbangan jumlah term ulul albab pada surat makkiyah dan madniyah memberi pemahaman bahwa ulul al-bab sama pentingnya di periode Makkah dan juga di periode Madinah. Manakala priode makkah dikenal masa membangun ketauhidan, menggiring, mendidik dan menyelamatkan umat dari berhalaisme ( 13 tahun), sudah barang tentu pada masa itu amat diperlukan ulul albab tidak berbeda dengan priode madinah

5 Muhammad Fuad Abdul Baqy ,Al Mu'jam al Mufarras Li AlFazil Quran ( Mesir : Daar al Fikr,1992),HIm. 818. 


\section{Armyn Hasibuan}

yang dikenal penyempurnaan syariah perundang undangan dan akhlak islam (10 tahun) juga memerlukan ulul al bab, yakni orang yang memiliki akal jenius, cendikiawan alias bijak. Orang bijak di tandai dengan memiliki akal murni, kecerdasan intlektual, yang tidak diselubungi kabut ide yang dapat memunculkan kerancuan berfikir, ia memahami petunjuk petunjuk Allah SWT merenungkan ketetapanNya dan melaksanakan semaksimal mungkin perintahNya sebagai pertanda yang telah memiliki hikmah. Maka makna ulul albab ( yang memiliki akal brilian) akan berkembang dinamis dan semakin menyingkap makna yang lebih luas dan kontemporer sesuai rangkaian dan korelasi serta munasabat ayat yang dirangkai dan merangkai kata atau istilah ulul albab itu sendiri. Quraish Sihab mengatakan ulul albab mampu menelusuri jalan jalan Allah SWT untuk diperhatikan dan dilaksanakannya dan terus menerus berupaya untuk tidak melaksanakan jalan jalan syetan yang membisikkan hal hal yang tidak baik bagi manusia. Sayang menurutnya,tidak semua orang menelusuri atau melakukan jalan jalan Allah.6Mafhum mukhalafah ( logikanya) hanya sedikit yang ulul albab.

\section{Hasil dan Pembahasan}

Apa arti dan pengertian dari Ulul al-Bab ? Untuk mengetahui pengertian ulul albab, harus lebih dahulu dipahami istilah kata ulu dan al bab. Ulu berarti (orang) yang empunya7atau memiliki. Apabila dirangkai dengan kata al amr ( urusan atau kekuasaan) berarti ulu al amr itu adalah

6 M.Quraish Sihab, Tafsir Al Misbah,Volume 1 ( Ciputat: Lentera Hati,2002,hlm.704.

${ }^{7}$ A.W.Munawwir, Kamus Al-Munawwir Arab-Indonesia Terlengkap (Yogyakarta: PONPES Al-Munawwir, 1984), hlm. 53. 
orang yang memiliki kekuasaan. ${ }^{8}$ Kemudian kata al bab berasal dari kata lubbun yang berarti inti, sari, bagian terpenting dari isi, otak, akal atau pikiran (intellect), ${ }^{9}$ Ulul al-Bab berarti yang mempunyai akal intlek (mind) yang beraneka ragam keintlekannya, karena kata al Bab berbentuk jamak, berarti dapat juga dipahami sedikit orangnya banyak kejeniusannya yakni berlapis lapis, paramufassir setara Pilosof.

Jalaluddin mengatakan sebagaimana dikutip oleh Rahmat Aziz bahwa ulul al bab adalah seorang cendikiawan muslim yang tangguh yang tidak hanya memiliki ketajaman analisis objektif tapi juga subjektif. ${ }^{10}$ sehingga dapat dikenal dari ciri cirinya antara lain : 1. Bersungguh sungguh dalam keilmuan, kesungguhannya mampu menjadikan fenomena fenomena alam pertukaran cuaca,iklim dan lingkungan hidup dapat jadi materi pembelajarannya. 2.Kemampuan menepis hal yang baik dan yang batil serta berkomitmen menegakkan kebenaran itu meskipun dipandang asing atau kurang loyal. 3. Kritis dan slektifmendengarkan pembicaraan,pandai menimbang ucapan,teori preposisi atau dalil yang dikemukakan orang lain.4. siap pakai untuk membagi ilmunya demi kemaslahatan ummat.5. Berani dengan kebenaran dan takutnya hanya karena Allah SWT.

Di dalam berbagai tafsir ditemukan arti ulul al bab dengan beraneka ragam pengertian sesuai konteksnya. Adapun konteks tentu melihat stressing utama pada ayat sebelum dan sesudahnya utamanya di dalam satu ayat kata apa yang digandengkan dengan ulul albab itu sendiri,

8M.Dawam Rahardjo, Ensiklopedi al Quran Tafsir Sosial Berdasarkan Konsep Konsep Kunci (Jakarta : Paramadina,1998), hlm.557.

9M.Dawam Rahardjo, Ensiklopedi al Quran Tafsir Sosial Berdasarkan Konsep Konsep Kunci (Jakarta : Paramadina,1998), hlm.558.

${ }^{10}$ Rahmat Azizi , Kepribadian Ulul Albab Citra Diri Dan Religiusitas Mahasiswa Di Era Globalisasi (Malang: UIN MALIKI PRESS,2011), hlm.40. 
Armyn Hasibuan

misalnya pada al Baqarah : 269 kata ulul al bab bergandengan dengan kata Hikmah,coba perhatikan ayat berikut:

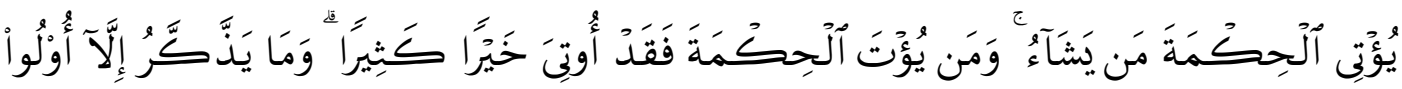
آلآنَلَْبْبِ

Artinya : Allah menganugerahkan Al Hikmah (kefahaman yang dalam tentang Alquran dan As Sunnah) kepada siapa yang dikehendakiNya. dan Barangsiapa yang dianugerahi hikmah, ia benar-benar telah dianugerahi karunia yang banyak dan hanya orang-orang yang berakallah yang dapat mengambil pelajaran (dari firman Allah).

Menurut penulis ulul al bab itu adalah orang bijak yang memiliki bukan saja satu kebijakan melainkan beraneka ragam kebijakan sehingga ayat itupun secara jelas mengatakan orang bijak ( orang bajik ) yang di maknai dari kata mufrad hikmah, apalagi memiliki banyak kebijakan tentu diberi kebaikan yang jauh lebih banyak lagi, hal inilah yang memasuki ranah ulul albab itu.

Menurut Ibnu Abbas $\rightarrow$ Ulul al-Bab yang ada dalam ayat di atas adalah orang yang mahir Alquran baik yang muhkamat, mutasyarihat, nasih, mansukh dan paham betul tentang isi kandungan Alquran itu sendiri. ${ }^{11}$

Ibnu al-Munzir mengatakan bahwa Ulul al-Bab adalah kenabian. ${ }^{12}$ Dari itu tidak ada salahnya manakala dikatakan Aristoteles, Plato, Zoro Aster, Si Budha Gautama, sebagai nabi di zamannya karena level kecerdasan dan kemampuan berfikirnya amat luar biasa dalam

${ }^{11}$ Rahmat Azizi , Kepribadian Ulul Albab Citra Diri Dan Religiusitas Mahasiswa Di Era Globalisasi (Malang: UIN MALIKI PRESS,2011), hlm.72.

${ }^{12}$ Asiruddin Abu Hayyan Al Andalusy, Tafsir Bahrul Muhit Juz 2, ( WWW.Waqfeya.Net ) Diunduh Selasa ,13-11-2018 Pkl 23.15. 
membimbing dan memberi berita yang berkaitan dengan penenangan jiwa manusia pada masa masing masing, terbukti filsafat-filsafat sebagai karya magdum mereka banyak yang masih diambil orang, sampai saat ini, seperti dalam agama Budha memiliki level yang tinggi dan bervariasi sebagai hasil logika berfikir pencetusnya yakni Budha Gautama (563 SM). Bukankah hal di atas serupa dengan cara kerja ulul al-bab?.

Mujahid menafsirkan, Ulul al-Bab adalah orang-orang yang berakal cerdas alias brilian, demikian juga Abdun ibn Hamid dan Ibn Zarir mengatakan Ulul $a l-B a b$ adalah orang yang memilki pemahaman Alquran dan ilmu pengetahuan lainnya, bukan hanya dibidang keagamaan tetapi kecerdasannya merambah di berbagai peraktik kehidupan global. ${ }^{13}$

Ibnu Abi Hatim $\rightarrow$ Ulul al-Bab adalah menguasai pemahaman isi dan pesan-pesan Alquran dan al Hadis.

Ibnu Zarir mengatakan Ulul $a l-B a b$ adalah orang yang tinggi pemahamannya. Abi Hatim mengatkan Ulul al-Bab adalah orang yang takut kepada Allah SWT yaitu pada Ulama. ${ }^{14}$

Contoh-contoh di atas ini, baru melihat rangkaian kata (term) al-Hikmah dengan Ulul al-Bab belum lagi memperhatikan kata (term) apa merangkai dan dirangkai oleh kata Ulul al-Bab itu sendiri.

Sebagaimana dikatakan sebelumnya bahwa ada 16 ayat Alquran yang di dalamnya terdapat ulul albab pada 10 surat, tetapi di kesempatan tulisan ini tidak semua di tampilkan. Adapun contoh kata atau istilah ulul albab di dalam ayat antara lain terdapat pada:

13Majid Hussain Qadri Rizvi, Al Maktabah al Waqfiyah, Waqfeya.Com Diakses Minggu,18 November 2018,Pukul 2200 Wib.

${ }^{14} \mathrm{Abu}$ Ja,Far Muhammad Bin Jarir Ath-Thabari, Tafsir Thobari, Juz 2, hlm. 176. 


\section{a. Q.S. Al-Baqarah : 269}

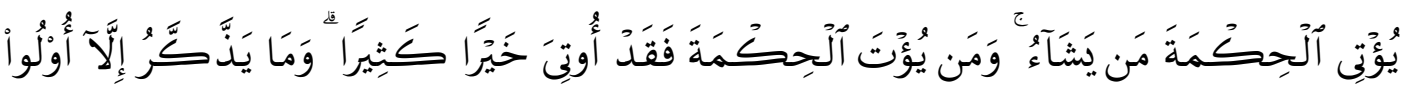

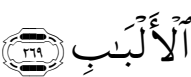

Artinya: Allah menganugerahkan Al Hikmah (kefahaman yang dalam tentang Alquran dan As Sunnah) kepada siapa yang dikehendaki-Nya. dan Barang siapa yang dianugerahi hikmah, ia benar-benar telah dianugerahi karunia yang banyak. dan hanya orang-orang yang berakallah yang dapat mengambil pelajaran (dari firman Allah).

\section{b. Q. S. Ali Imran : 7 dan 190-191}

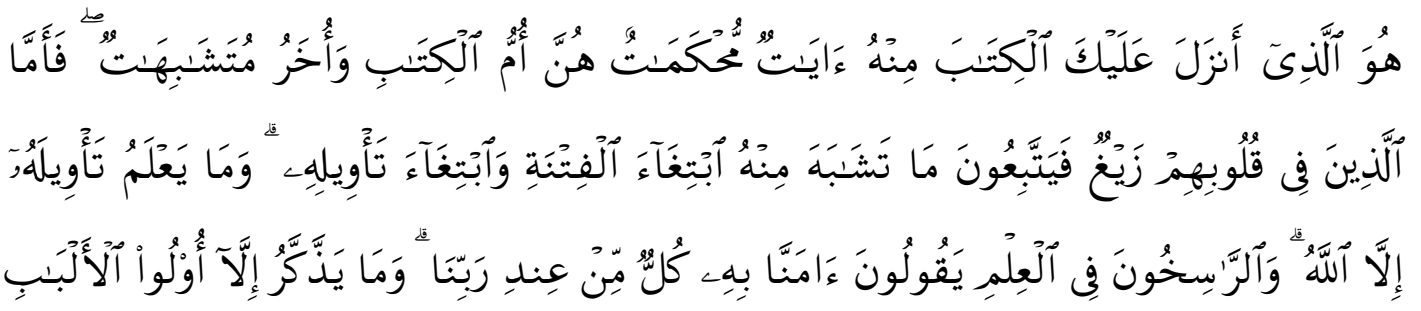

Artinya: Dia-lah yang menurunkan Al kitab (Alquran) kepada kamu. di antara (isi) nya ada ayat-ayat yang muhkamaat, Itulah pokok-pokok isi Al qur'an dan yang lain (ayat-ayat) mutasyaabihaat. Adapun orang-orang yang dalam hatinya condong kepada kesesatan, Maka mereka mengikuti sebahagian ayat-ayat yang mutasyaabihaat daripadanya untuk menimbulkan fitnah untuk mencari-cari ta'wilnya, Padahal tidak ada yang mengetahui ta'wilnya melainkan Allah dan orang-orang yang mendalam ilmunya, berkata: "Kami beriman kepada ayat-ayat yang mutasyaabihaat, semuanya itu dari sisi Tuhan kami." dan tidak dapat mengambil pelajaran (daripadanya) melainkan orang-orang yang berakal. 
Adapun yang menjadi stressing utama dalam ayat di atas adalah memaknai illallohu warraskhun, yang memberi nuansa ayat mutasyabih hanya di ketahui oleh Allah dan orang yang rasih. Menurut penulis orang yang rasih itu adalah para mufassir sekaligus bertaraf pilosof.

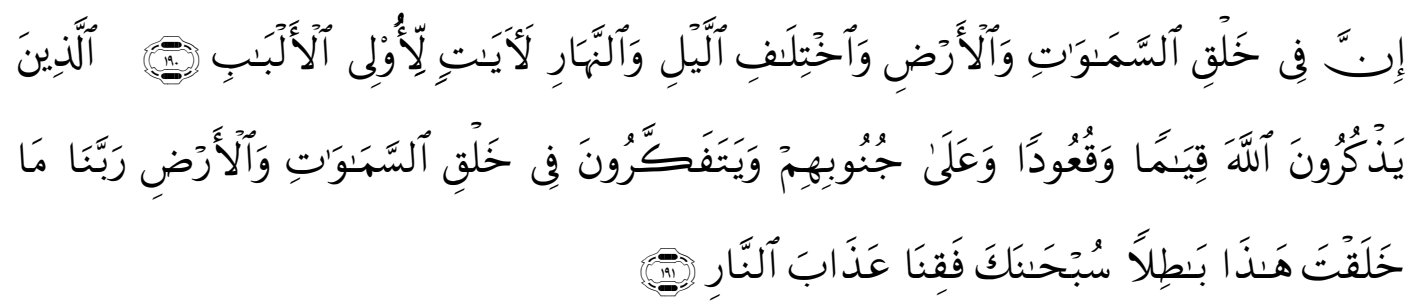

Artinya: Sesungguhnya dalam penciptaan langit dan bumi, dan silih bergantinya malam dan siang terdapat tanda-tanda bagi orang-orang yang berakal, (yaitu) orang-orang yang mengingat Allah sambil berdiri atau duduk atau dalam keadan berbaring dan mereka memikirkan tentang penciptaan langit dan bumi (seraya berkata): "Ya Tuhan Kami, Tiadalah Engkau menciptakan ini dengan sia-sia, Maha suci Engkau, Maka peliharalah Kami dari siksa neraka.

C. Q. S. Shad : 29

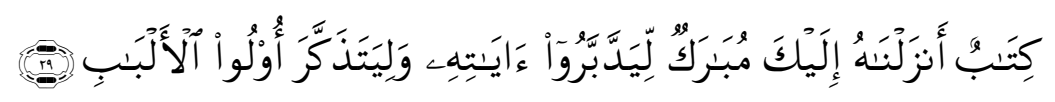

Artinya: Ini adalah sebuah kitab yang Kami turunkan kepadamu penuh dengan berkah supaya mereka memperhatikan ayat-ayatNya dan supaya mendapat pelajaran orang-orang yang mempunyai fikiran.

\section{d. Q. S. Azzumar : 18 dan 21}

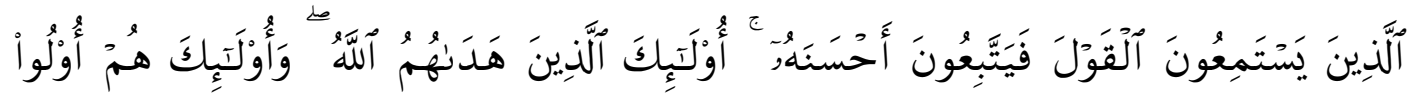

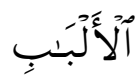




\section{Armyn Hasibuan}

Artinya: Yang mendengarkan Perkataan lalu mengikuti apa yang paling baik di antaranya mereka Itulah orang-orang yang telah diberi Allah petunjuk dan mereka Itulah orang-orang yang mempunyai akal.

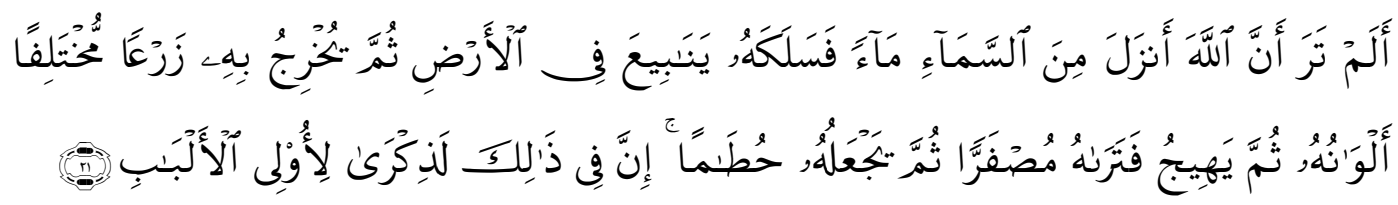

Artinya: Apakah kamu tidak memperhatikan, bahwa Sesungguhnya Allah menurunkan air dari langit, Maka diaturnya menjadi sumber-sumber air di bumi kemudian ditumbuhkan-Nya dengan air itu tanam-tanaman yang bermacam-macam warnanya, lalu menjadi kering lalu kamu melihatnya kekuning-kuningan, kemudian dijadikan-Nya hancur berderai-derai. Sesungguhnya pada yang demikian itu benar-benar terdapat pelajaran bagi orang-orang yang mempunyai akal.

Dengan demikian Ulul al-bab berarti yang mempunyai akal yaitu orang yang cerdas memiliki kebijaksanaan (hikmah), kaya ide, pelopor, penebar kebaikan untuk kemaslahatan kemanusiaan, memiliki komitmen tinggi untuk mengintegrasikan zikir,fikir dan amal shaleh, mampu menyalin informasi dan komunikasi dan mengikuti yang terbaik, penuh kehati-hatian berbudi pekerti yang baik dan memilki kedalaman spiritual dan kemapanan profesi.

\section{Kesimpulan dan Saran-saran}

Dengan rangkaian-rangkaian ayat Alquran secara munasabah dengan pendekatan tematik dan ma'tsur akan terasa semakin indah, halus dan kaya makna yang dikandung oleh ulul al-bab. Walupun mereka genius, tinggi inteligensi dan shaleh dengan penampilan namun mereka tidak sombong bahkan amat berhati-hati, tidak mau mendahului keinginan Allah, sehingga memahami wahyu Allah SWT penuh kehati-hatian. Kajian ulul al 
bab memiliki kajian yang sangat luas. Untuk itu, masih berpeluang direspon lewat sudut pandang yang berlainan.

\section{Daftar Pustaka}

A.A. Dahlan Dan M. Zaka Al-Farisi, Asbabun Nuzul Latar Belakang Historis, Turunnya Ayat-Ayat Alquran, Bandung: CV.Di Ponegoro, 2007.

Abdurrahman Jalaluddin Assuyuti, Tafsir al-Ma'tsur (Https://la902808.Us.Archive.Org), Diakses Senin, 12-11-2018, Pkl. 14.00 .

Abu Ja,Far Muhammad Bin Jarir Ath-Thabari, Tafsir Thobari, Juz 2.

Akmal N Asery B, Percakapan Cendikiawan Tentang Pembaharuan Pemikiran Islam Di Indonesia, Bandung: Mizan,1996.

Asiruddin Abu Hayyan Al Andalusy, Tafsir Bahrul Muhit Juz 2, ( WWW.Waqfeya.Net ) Diunduh Selasa ,13-11-2018 Pkl 23.15.

A.W.Munawwir, Kamus Al-Munawwir Arab-Indonesia Terlengkap, Yogyakarta: PONPES Al-Munawwir, 1984.

Depag R.I., Alquran Dan Tarjamahnya, Jakarta: Lijnah Tahsis Quran,1990.

Fathu Qadir Syaukany, Al Maktabah Syamilah ,Http://Id.m.Wikipedia.Org Diakses Minggu 18 November 2018 Pukul 20.05.

Ibn Taimiyah, Tafsir al-Kabir, Juz 2, Beirut: Dar al-Kutub al-IImiyah, t.t.

Imam Bawani Dan Isa Anshari, Cendikiawan Muslim Dalam Perspektif Pendidikan Islam, Surabaya: PT. Bina IImu, 1991.

Majid Hussain Qadri Rizvi, Al Maktabah al Waqfiyah , Waqfeya.Com Diakses Minggu,18 November 2018,Pukul 2200 Wib.

M.Dawam Rahardjo, Ensiklopedi Alquran Tafsir Sosial Berdasarkan Konsep Konsep Kunci, Jakarta : Paramadina,1998. 
Armyn Hasibuan

M.Quraish Sihab, Tafsir Al Misbah,Volume 1, Ciputat : Lentera Hati,2002.

Muhammad Fuad Abdul Baqy ,Al Mu'jam al Mufarras Li AlFazil Quran, Mesir : Daar al Fikr,1992.

Rahmat Azizi, Kepribadian Ulul Albab Citra Diri Dan Religiusitas Mahasiswa Di Era Globalisasi, Malang : UIN MALIKI PRESS,2011.

Sahilun A. Nasir, Pendidikan Agama Islam Di Perguruan Tinggi, Surabaya: Al;lkhlas, 1998. 